Tomislav Stojanov, tstojan@ihjij.hr, tstojan@gmail.com

Institute of Croatian Language and Linguistic

Republike Austrije 16, 10.000 Zagreb, Croatia

\title{
ORTHOGRAPHIC LITERACY AS METHODOLOGICAL GUIDELINE FOR ORTHOGRAPHIC STANDARDIZATION
}

\begin{abstract}
This paper discusses the impact of orthographic manuals on the state of literacy, i.e. the relation of orthographic literacy and orthographic standardisation. The established hypothesis claims that frequent changes of orthographic rules during the pupils' primary and secondary education do not have any considerable impact on their orthographic habits. In other words, the quantity of orthographic mistakes observed during a longer period of time and in conditions of changed orthographic rules would not show significant oscillations in their spelling. In order to confirm the hypothesis, a questionnaire was conducted encompassing 41 tests among 526 students of a technical study programme during four consecutive academic years, pursuant to whose results a writing uniformity index and a categorisation of orthographic controversy into six classes is established. The Croatian language has been selected for the observation due to multiple orthographic changes in the last 30 years in the three major orthographic points: writing of the covered $r$, writing of $d$ and $t$ in front of $c$ and $\check{c}$ in declination of words ending in $-t a k$, -tac, -dak and -dac, and the issue of compound or separate spelling of the negation particle and the auxiliary biti (to be).

Moreover, the paper methodologically and quantitatively establishes criteria according to which the second established hypothesis on evolutionary orthographic literacy can be confirmed. The conclusions are expected to be able to contribute to the better understanding of orthographic planning and application of orthographic norms in schools.
\end{abstract}

Key words: orthographic literacy; questionnaire research; Croatian orthography; (de)standardisation

\section{Introduction}

Measurement and monitoring of written language is one of the important activities of language authorities. For example, the Danish Language Council (Dan. Dansk Sprogncevn), as one of the highly developed language regulatory bodies in Europe in questions of orthographic standardisation methodology and technology, created language corpora in the genre of journalism for the purpose of monitoring the development of contemporary Danish. ${ }^{1}$ As many as two of the three main tasks are related to orthographic methodology (monitoring the development of Danish and research of accepted writing conventions).

Monitoring language changes is a current issue of corpus linguistics and represents a special corpus discipline, described already by Sinclair (1982 and 1991) and for which McEnery (2003: 451) emphasised the importance of the principles of balance and representativeness (for our needs we would also add dynamics - the principle of necessity for the corpus to grow continuously to monitor the contemporary status of a language). Language normativists participate in the development of methodology for monitor corpora. Contrary to the corpus approach (e.g. Asmussen 2006), the centre of literacy monitoring research in this paper is based on a questionnaire survey some of the more controversial orthographic issues of Croatian orthography.

The research was inspired by the public opinion that ,orthographic manuals may change, but the majority will always write in the same way“. The sociolinguistically relevant issue is raised as to which extent orthographic manuals influence writing and how much orthographic practice truly changes under the influence of orthographic changes. If the spelling rules for reflection of Proto-Slavic jat in Croatian have proven to be relatively stable over

\footnotetext{
${ }^{1}$ KorpusDK - 56-million corpus covering texts crated from 1990 to 2010 (http://ordnet.dk/korpusdk). Recent texts are sourced from a pressclipping agency InfoMedia (http://infomedia.dk/) which made its business model in an interesting way available to normative linguists. This way they are able to analyse language material from Danish media on a daily basis.
} 
time, but many mistakes are still made in this respect - what does this discrepancy tell us. Does the problem lie in the rules and orthographic manuals, in the school system or in individuals? If it is about the rules, should orthographers consider changing them to make learning rules easier? If it is the school system, should we listen to the methodicians who speak of the need to put orthographic contents in a separate educational curriculum or at least into "separate units of language content" (Težak 1996: 57)? To which extent will the forthcoming curricular reform in Croatia impact orthographic literacy? Do we need, in accordance with the expected greatly amended concept of curriculums for Croatian language education, also new conceptual versions of orthographic manuals? Is it possible to interlink them better to the competences from the CEFRL (2005)? These and numerous other general questions on the course of orthographic (de)standardisation require the monitoring of orthographic usage as compared to the norm.

If we agree with the opinion on the "absurd condition of orthographic literacy", as pointed out by Reljac Fajs and Jerković (2014: 37), that orthographic content is present in the Croatian language education from the first grade of primary school until the end of secondary education, but that the literacy of our pupils continues to be below average, the research question becomes even more relevant.

\section{Hypothesis}

Investigating the relation between orthography and literacy is part of wider interdisciplinary literacy research incorporating educational sciences such as psychology, pedagogy, didactics, linguistics, sociology and similar disciplines. Orthography is observed within a wider context of language acquisition, development of literacy, phonology, prosody, the relation of writing to reading, bilingualism, language reforms, language policy etc. (Aram and Korat 2010, Joshi and Aaron 2006, Templeton and Bear 2013, Coulmas and Guerini 2012, Street 2013). In this research, orthographic literacy is analysed in the context of orthographic planning. It is being investigated to which extent "official" orthographic solutions acquired during primary and secondary education are applied after the pupil finishes that part of education. The results are expected to be valuable for orthographic planning, a topic which is considered to be neglected in orthographic literacy discussions. In addition to it, the results could present a valuable contribution with their insights into the status of language policy and orthographic ideology for Croatian in the past 30 years. The research methodology is based on questionnaires and their analyses. Descriptions of survey results on the knowledge of Croatian orthography have been found in Aladrović (2008), Alerić and GazdićAlerić (2009), Grgić and Udier (2012), Reljac Fajs and Jerković (2014), Volanec (2015), Patekar (2016), and Udier (2016). The first paper investigates orthographic competencies of 60 pupils of the first grade of primary school. The second paper researches an interestingly established connection between a positive attitude to the Croatian standard language and the knowledge of orthographic rules of Croatian based on a survey of 155 students of the Croatian language and literature, primary and pre-school education at the University of Zagreb. Grgić and Udier provide a survey analysis of orthographic competencies at B1 level of Croatian as foreign language. Reljac Fajs and Jerković have surveyed 202 pupils of primary education, from the first to fourth grade, on the pupils' interests for orthographic content and their problems in acquiring orthographic rules. The Volanec paper is important for this research because it has a similar topic: it questions the relation between orthographic standard and use by surveying 200 persons using examples also mentioned in this paper. Patekar compared orthographic knowledge of Croatian and English by studying writing of 48 students. The last paper mentioned uses the results of orthographic questionnaires in glottodidactic observation of explicit and implicit orthography teaching. A survey of thirty 
Croatian teachers in the higher grades of primary schools in different regions of Croatia is also mentioned by Škarić (2005: 85) within his wider investigation of the relation between ije and je. Barbaroša-Šikić and Češi (2010) surveyed 336 Croatian language teachers in elementary schools for the purpose of monitoring, evaluation and assessment of pupils' literacy.

The research hypothesis claims that changes of orthographic rules during the pupils' primary and secondary education do not have a significant impact on their orthographic habits. In other words, the number of orthographic mistakes observed during a longer period of time and in conditions of changed orthographic rules would not show major oscillations in their spelling. The Croatian language situation is particularly interesting due to the frequent changes of three orthographic points in question. The second hypothesis relates to evolutionary orthographic literacy - the more stable the rules, the fewer mistakes are made and generations of speakers become "more and more literate". It is represented in the public in the form of the opinion "it is best to have an orthography which changes least". 2

Although a less complex research could have been carried out using only typical orthographic examples which are proven to be source of mistakes by students (e.g. $\check{c}$ and $c, i j e$ and je in Croatian), it was assessed that interesting results could be obtained using examples whose spelling rules have changed in the recent orthographic manuals since in this way our assumptions on orthographic habits could be confirmed more conclusively. ${ }^{3}$ The questionnaire was thematically narrowed down to three orthographic items with different standards in the Croatian orthographic manuals and which were or are still recommended for use in schools: compound or separate spelling of the negation particle, writing of consonants $d$ and $t$ in front of $c$ and $\check{c}$ in the declination of words ending in -tac, $-t a k,-d a c$ and $-d a k$, and writing of $j$ after covered $r$.

The survey results of four generations of students in academic years 2011/2012, 2012/2013, 2013/2014, 2014/2015 will be compared, who were during their primary and secondary education (from school year 1999/2000 to 2013/2014) officially taught pursuant to two orthographic manuals - from the fifth edition of BFM from year 2000 to the first edition of BHM. Orthographic solutions stated in them are identical - both orthographies prescribe the non-compound spelling of the negation, writing of consonants $d$ and $t$ in front of $c$ and $\check{c}$, and writing of je in the covered $r$. Although, theoretically speaking, the BFM orthography manual was continuously recommended for use in primary and secondary schools from 1994 till 2005 , Reljac Fajs and Jerković claim that all orthographic manuals were ,approved and valid“ (2014: 40). It is difficult to establish now which orthographic solutions the pupils met and in which way they were instructed by their teachers ${ }^{5}$, but the answer is actually not vital, since the orthographic manual of the Institute for Croatian Language, which became official as of school year 2013/2014, introduced changed rules according to which the conclusions on the research hypothesis will be made in the long term. The hypothesis on the connection between writing and literacy can only be verified by comparing the longterm survey results of pupils who started primary school in school year 2013/2014 and enrolled the Zagreb

\footnotetext{
2 [self-identification citation temporarily erased]

${ }^{3}$ The issue of $\check{c} / c ́$ and ije/je have not been systematically changed since the end of World War II.

${ }^{4}$ Some authors think that the BFM orthography lost this recommendation after its $4^{\text {th }}$ edition due to major orthographic changes undertaken in the $5^{\text {th }}$ edition. „The truth was that the fourth edition had such permission, as opposed to later, essentially amended editions“ (Peti-Stantic and Langston 2013: 199-200). We have not found conclusive evidence for this claim. More space to orthographic legislation will be dedicated in a forthcoming research.

${ }^{5}$ Bakota (2011) pointed out that the textbooks for Croatian Language lessons were mostly in line with the conclusions of the Council for the Norms of the Croatian Standard Language (i.e. BFM orthography manuals), as opposed to the textbooks of mathematics, nature and society (cro. priroda i društvo), and music education (cro. glazbena kultura) in which alternative writing can be found.
} 
Polytechnic in academic year 2024/2025 (where questionnaires have been conducted). IHJJ (2013) diverges from these orthographic solutions in two points: the compound spelling of the negative particle is default and alternative spelling of $j e$ is allowed in certain words containing the covered $r$. The IHJJ orthographic manual was official only in the last surveyed generation, and only in the last year of their secondary education. It is assumed that, in the first year of use, its orthographic norms have not been decisive in acceptance of pupils of the last year of secondary school for them to have a major impact on survey results.

\section{Table 1. List of official orthographies for Croatian and their solutions}

\begin{tabular}{|c|c|c|c|c|c|}
\hline $\begin{array}{c}\text { orthographic } \\
\text { manual }\end{array}$ & governmental body & period in force & neću or ne ću & $\begin{array}{l}\text { podaci or } \\
\text { podatci }\end{array}$ & $\begin{array}{c}\text { sprečavati or } \\
\text { sprječavati }\end{array}$ \\
\hline $\begin{array}{c}\text { AS }^{6} 1986 \mathrm{i} \\
1987\end{array}$ & $\begin{array}{l}\text { Commission for language at the } \\
\text { Committee for Education, Culture, } \\
\text { Sport and Technology of Socialistic } \\
\text { Republic of Croatia (cro. Komisija za } \\
\text { jezik pri Komitetu za prosvjetu, kulturu, } \\
\text { fizičku i tehničku kulturu SRH) }\end{array}$ & $1986-1990$ & neću & podaci & sprečavati \\
\hline $\begin{array}{l}\text { BFM } 1994 \text { i } \\
1995\left(2^{\text {nd }} \text { and }\right. \\
\left.3^{\text {rd }} \text { ed. }\right)\end{array}$ & \multirow{3}{*}{$\begin{array}{l}\text { Ministry of Culture and Education, } \\
\text { document class } 602-09 / 94-01-08 \text {, } \\
\text { number } 532-02-01 / 5-94-01\end{array}$} & \multirow{3}{*}{$18 / 04 / 1994-15 / 02 / 2005$} & both & both & both \\
\hline $\begin{array}{l}\text { BFM } 1996 \text { (4th } \\
\text { ed.) }\end{array}$ & & & both & both $^{7}$ & both \\
\hline $\begin{array}{l}\text { BFM } 2000\left(5^{\text {th }}\right. \\
\text { ed.), } 2002 \\
2003,2004 \\
2006\end{array}$ & & & ne ću & podatci & sprječavati \\
\hline $\begin{array}{l}\text { BHM 2005, } \\
2008\end{array}$ & $\begin{array}{l}\text { Ministry of Science, Education and } \\
\text { Sport, document class } 602-09 / 05- \\
01 / 0007 \text {, number } 533-12-05-02\end{array}$ & $16 / 2 / 2005-31 / 7 / 2013$ & ne ću & podatci & sprječavati \\
\hline $\begin{array}{c}\text { BMM 2007, } \\
2008\end{array}$ & $\begin{array}{l}\text { Croatian Education and Teacher } \\
\text { training Agency (cro. Agencija za odgoj i } \\
\text { obrazovanje), document 602-09/12- } \\
\text { 01/0013, number: 561-05/21-13-3 }\end{array}$ & $28 / 2 / 2013-11 / 11 / 2013^{8}$ & neću & podaci $^{9}$ & sprečavati $^{10}$ \\
\hline IHJJ 2013 & $\begin{array}{c}\text { Ministry of Science, Education and } \\
\text { Sport, class } 602-01 / 13-01-00789 \\
\text { number } 533-18-13-0002 \\
\text { http://public.mzos.hr/fgs.axd?id=20543 }\end{array}$ & $31 / 7 / 2013$ & neću $u^{11}$ & podatci $^{12}$ & both $^{13}$ \\
\hline
\end{tabular}

In accordance with the above table, there have been seven groups of official Croatian orthographic manuals since 1986 with regard to the spelling of the three test examples. ${ }^{14}$ In two of them, the separate spelling of the negative

\footnotetext{
6 There are no data on official recommendation for the third edition of 1990

7 Two-syllable words keep the letter $t$ or $d$, as opposed to three-syllable or multi-syllable words, in which both writings are normative (BFM 1996: 48).

${ }^{8}$ On 11 November 2013 the Croatian Education and Teacher training Agency passed a regulation pursuant to which orthographies are no longer considered educational aids, thus removing this orthography from official use in schools. http://www.azoo.hr/images/razno/Pravilnik PNS studeni 2013.pdf (visited 10. 5. 2017.)

${ }^{9}$ Although rule $\$ 50$ in translation version says that "consonants $\mathbf{d}$ and $\mathbf{t}$ can $(\ldots)$ be written in front of $\mathbf{c}$ and $\check{\mathbf{c}}$ when the root of the word is to be preserved", none of the following forms is registered in the orthographic dictionary: bitci (of bitak), jadci (of jadac), kutci (of kutak), mladci (of $m l a d a c$ ), petci (of petak), usadci (of usadak). Despite nominal approval of alternate spelling, it is obvious that one form is preferred, which is the reason for such determination in the table.

${ }^{10}$ It is interesting to note that alternate spelling is allowed for only one example in the orthographic dictionary (sprečavati and sprječavati).

11 The IHJJ orthography introduces the methodological novelty regarding alternate spelling by introducing the categories of the recommended and the allowed. For the negation particle, the recommended spelling is compound, which is why this form is stated as primary.

${ }^{12}$ As for the previous note, alternative forms (podaci, dodaci...) are noted in the dictionary as allowed, establishing the forms podatci, dodatci etc. as primary.

${ }^{13}$ Among the rules of the covered $r$ there is no category of recommended and allowed writing, which would make it easier to determine the primary form. Although the spelling of the covered $r$ relates only to a part of the words (derivatives of the words grijeh, spriječiti and unaprijediti, or forms of one-syllable masculine nouns which do not have a long raising (cro. dugouzlazni) accent in genitive singular - brijeg, crijep, grijeh, krijes, vrijes and $\check{z}$ drijeb), judging by the orthographic dictionary (using of the conjunction $i$ and listing both words in the word list), those forms are considered equal.

${ }^{14}$ Comparing only prescribed forms and excluding the IHJJ 2013 orthographic manual (which was published 3 years after), Hudeček established three groups (2010: 43). Using the same methodology, we would divide into four groups, since we would split BFM orthographies into three classes (instead of Hudeček's two): before the $4^{\text {th }}$ edition, $4^{\text {th }}$ edition, and editions thereafter.
} 
particle is prescribed, in another two, compound and non-compound spelling is established as equally valid, and in three, the compound spelling is preferred. Regarding the writing of $t$ and $c$ in front of $c$ and $\check{c}$, three orthographic manuals prescribe that they should be written, in one of them, they are equally valid, in another one, there is a mixed solution, and in two manuals, their omission is prescribed. The writing of $j$ in words with covered $r$ is considered correct in two manuals, in three of them, both are equally valid and in two, the official spelling is their omission.

Consequently, we can make a general conclusion that three orthographic practices exist in the spelling of these three examples: the first are AS and BMM, the second are BHM and BFM (with its evolutionary amendments), whose solutions are completely opposite to the first practice. The third practice is IHJJ as a combination of the first two options.

„Even though the use in schools is one of the most important segments of implementation of language policy and although it represents the widest basis, it should still be pointed out that it certainly does not represent the totality of official language nor the language in official use.“ (translated from Peti-Stantić \& Langston 2013: 198) We can agree with this statement, however since the object of our research are orthographic habits of students who have just finished secondary education, the issue of official orthographic manuals and rules is for us an important referential point for further research.

\section{Survey method}

\subsection{Questionnaire surveys in orthographology}

When carrying out orthographic surveys, greater methodological and implemental austerity should be required than is usual for humanistic and social sciences. Due to the significant relation between language and identity, surveys can be a manipulative means of spreading political ideas, which Bašić (2014) calls „survey linguistics“. Tadijanović, a famous Croatian poet, complained that "nothing good has come from any survey of this kind, since Skerlić in 1914 (...) until the Novi Sad survey in 1953“. (Translated from Tadijanović 2005: 103.) There have been several such surveys for the purpose of orthographic planning covering speakers of Croatian: the 1858 Klun-Karadžić survey, the 1912 survey of the Slovenian magazine Veda, the 1914 Skerlić survey and the 1953 Matica srpska survey. The latter is of special importance because in accordance with it the Novi Sad Agreement was established, whose principles were implemented in the 1960 Orthography of the Serbocroatian Standard Language (Pravopis hrvatskosrpskoga književnog jezika) of Matica hrvatska and Matica srpska. The less-known survey of Srpski književni glasnik in 1922, which is discussed by Páll (2009), can be added to this list. Although it deals with political questions, survey participants also stated their opinion on language and writing, like in the 1914 survey. The orthographic norms of Novi Sad agreement in 1960 and their influence on contemporary Croatian orthographic practice are still debated today. In recent times, the survey of the Language Committee of Matica hrvatska in 1992 and the survey of the Croatian Language Norm Council in 1998 are well known, since they set the contemporary direction for orthographic practice of Croatian language. It can be noted that all surveys are exclusive and of a closed type, and thus of a very limited statistical size. In addition, none of them has scientific research as its goal, but the advisory or implementing role of language policy. Orthographic surveys should be anonymous since otherwise they provide opportunity for manipulation in the interpretation of the results obtained, for example pursuant to the criterion of power of authority or influential individuals. Contemporary European public opinion survey standards have strongly supported the policy of privacy protection of individuals, strictly 
regulating the ethical conditions for use of personal data, such as the disclosure of name and surname. In addition, survey methodology must be well documented and publicly available, and the survey results must meet the principles of data management. It is due to the experience of the influence of surveys on the orthographic standardisation of Croatian so far that surveys should pay more attention to establishing implementation criteria and principles for reaching conclusions. Such metascientific research is typical in medicine, which is renowned for research austerity and ethics, e.g. Lydeard (1991), Stone (1993), and Eaden, Mayberry and Mayberry (1999).

\subsection{Survey description}

The survey was conducted during four consequent academic years with a total of 526 students: 130 in year 2011/2012, 117 in year 2012/2013, 150 in 2013/2014, and 129 in 2014/2015. Those were the students of computer technologies at the Zagreb Polytechnic in their first study year. For technical reasons, in academic year 2012/2013 the survey had to be conducted among students who had enrolled their $3^{\text {rd }}$ semester, but who had not completed the questionnaire before. The surveys were conducted on 15 October 2012, 7 March 2013, 7 October 2013 and 15 October 2014. The questionnaire was adopted from Milica Mihaljević and Lana Hudeček, both researchers at the Institute of Croatian Language and Linguistics (see Appendix 1).

The questionnaire had not been announced in advance, so the students could not prepare for it. In the beginning of the questionnaire, the survey's purpose for the needs of orthographologic research was mentioned and only the basic information on the manner of filling out the questionnaire was provided. The solutions were neither suggested nor spoken out. The dictation sentence „nećemo/ne ćemo ispravljati pogreške/pogrješke u Johnnyjevim/Johnnyevim zadatcima/zadacima“"15 was spoken out clearly. For clarification, students were told to imagine that Johnny from the sentence is the person Johnny Cash (for clearer distinction to John Wayne or any third name with adopted spelling in Croatian). The questionnaire was conducted on paper, since it was assessed that by a computerised approach the participation would be substantially reduced. Only relevant answers were taken into account. Irrelevant answers (e.g. illegible, completely missed answers or playful remarks) are listed in the category "other". Answers represented by more than 5\% were considered relevant statistical samples and are printed in italics in the tables. Incorrect spellings of the jat reflection were not considered irrelevant answers, so they are also listed in the tables. Furthermore, the numerous answers provided by students as the plural form of the word ,iscjedak“ were intentionally left because of their significance. This quantity represents information to orthographers that the students „feel“ that something is wrong with the normative form ,iscjeci“, but that they are not educated enough to write ,iscjedci“. All such and similar examples were noted (e.g. "redtci” as plural of "redak").

Table 2. Table overview example of survey results

\begin{tabular}{|c|c|c|c|}
\hline academic year & \multicolumn{3}{|c|}{$2011 / 2012$} \\
\hline answers & token & abs. & rel. \\
\hline number & patci & 97 & $85.1 \%$ \\
\hline 1. & patke & 7 & $6.1 \%$ \\
\hline 2. & patki & 4 & $3.5 \%$ \\
\hline 3. & paci & 2 & $1.8 \%$ \\
\hline 4. & pataci & 2 & $1.8 \%$ \\
\hline 5. & [other] & 2 & $1.8 \%$ \\
\hline 6. & patci $98 \%-$ paci $2 \%$ \\
\hline standard forms ratio
\end{tabular}

\footnotetext{
15 In English translation: ,we will not correct mistakes in Johnny's lessons“.
} 
The + (plus) sign next to the number of total answers marks the number of students who provided more than one answer. The designation " $113+1$ " marks a total of 114 answers provided by 113 students (i.e. one student provided an alternate solution). Even though there were very few double answers (triple or multiple ones did not occur), we wanted to preserve this information for reasons of surveys method accuracy. For marking duplicity, the students used the slash sign or brackets, for example "grijesi/grehovi” or "pe(t)ci".

Questionnaire processing at the bottom of each table provides information about the ratio of only standard forms for easier review of table data. Standard forms were taken to be the forms prescribed as recommended or allowed by contemporary Croatian orthographies. Thus, it was considered that both podaci and podatci, crepovi and crjepovi, neću and ne ću are standard forms. The so called short plural forms (crijepi, grijesi, brijezi), although being in line with the grammar rules of Croatian, were not categorized as standard lexical forms because they are stylistically marked. The relation crepovi-crjepovi, grehovi-grjehovi, bregovi-brjegovi was observed instead. On the other hand, all dative forms pripovijetci-pripovijetki-pripovijeci, zagonetci-zagonetki-zagoneci, and žabovlatci - žabovlatki - žabovlaci were considered standard. The word žabovlatka was intentionally chosen as a less common lexical unit (botanical term) intended to test the morphological dative formation in relation to pripovijetka and zagonetka.

Due to a great amount of survey data, the results (scanned questionnaires in PDF-format, table data in excel-format, questionnaire in word-format and all other auxiliary papers) are stored on cloud, on the ReLDI ${ }^{16}$ project repository and on the personal Academia.edu ${ }^{17}$ pages. This is where the results of all future questionnaires in the years to come shall also be stored.

\section{Measurements and indicators}

Table 3 shows summary survey results during four academic years. The dominant forms are shown in the examples column. To the total number of 37 test examples another four points interesting for survey processing of orthographic writing were added: in addition to brežuljak and brježuljak, the forms brežić and brježić were monitored (all diminutives of brijeg). The survey results were interpreted not only in the mutual relation of the correct forms, but also of orthographically alternative forms: Johnnyjevim versus Johnnyevim and Johnnyjevim/Johnnyevim versus Džonijevim/Đonijevim.

The column in which the year is stated provides data on the form occurrence result as compared to the alternative orthographic forms, e.g. the form patci in 2012 has a value of $98 \%$, meaning that the relation between patci and paci is $98 \%$ versus $2 \%$.

Table 3. Summary overview of survey results $2012-2015$

\begin{tabular}{|c|c|c|c|c|c|c|c|}
\hline Examples & 2012 & 2013 & 2014 & 2015 & $\begin{array}{c}\text { Average } \\
2012-2015\end{array}$ & $\begin{array}{c}\text { Deviation } \\
\text { Index }\end{array}$ & Relevance Index \\
\hline petci & $100 \%$ & $100 \%$ & $98.5 \%$ & $98.2 \%$ & $99.2 \%$ & $1.8 \%$ & $90.3 \%$ \\
\hline patci & $98 \%$ & $96.6 \%$ & $94.7 \%$ & $98 \%$ & $96.8 \%$ & $3.3 \%$ & $83.7 \%$ \\
\hline iscjedci & $100 \%$ & $99 \%$ & $100 \%$ & $100 \%$ & $99.7 \%$ & $1 \%$ & $74 \%$ \\
\hline redci & $84 \%$ & $85 \%$ & $79 \%$ & $89.5 \%$ & $84.4 \%$ & $10.5 \%$ & $50.8 \%$ \\
\hline
\end{tabular}

16 https://reldi.spur.uzh.ch/

17 https://ihjj.academia.edu/TomislavStojanov 


\begin{tabular}{|c|c|c|c|c|c|c|c|}
\hline bitci & $94 \%$ & $97 \%$ & $95.6 \%$ & $91.3 \%$ & $94.5 \%$ & $5.7 \%$ & $86.1 \%$ \\
\hline nebitci & $90 \%$ & $98 \%$ & $93.1 \%$ & $90.8 \%$ & $93 \%$ & $8 \%$ & $85.2 \%$ \\
\hline preci & $74 \%$ & $69 \%$ & $68.2 \%$ & $73.2 \%$ & $71.1 \%$ & $5.8 \%$ & $53.1 \%$ \\
\hline napredci & $92 \%$ & $93 \%$ & $91.6 \%$ & $94 \%$ & $92.6 \%$ & $2.4 \%$ & $56.3 \%$ \\
\hline napitci & $81 \%$ & $83 \%$ & $83.8 \%$ & $85.7 \%$ & $83.4 \%$ & $4.7 \%$ & $82.4 \%$ \\
\hline pripovijetci & $96 \%$ & $84 \%$ & $84 \%$ & $82.3 \%$ & $86.6 \%$ & $13.7 \%$ & $36.7 \%$ \\
\hline zagonetci & $71 \%$ & $81 \%$ & $74.1 \%$ & $75.9 \%$ & $75.5 \%$ & $10 \%$ & $70.8 \%$ \\
\hline crjepovi & $100 \%$ & $100 \%$ & $100 \%$ & $100 \%$ & $100 \%$ & $0 \%$ & $12.7 \%$ \\
\hline zadaci & $51 \%$ & $60 \%$ & $50.6 \%$ & $57.9 \%$ & $54.9 \%$ & $9.4 \%$ & $54.2 \%$ \\
\hline podaci & $62 \%$ & $57 \%$ & $52.7 \%$ & $54.8 \%$ & $56.6 \%$ & $9.3 \%$ & $54.5 \%$ \\
\hline brjegovi & $82 \%$ & $85 \%$ & $81.8 \%$ & $69.2 \%$ & $79.5 \%$ & $15.8 \%$ & $9.5 \%$ \\
\hline grjehovi & $100 \%$ & $87.5 \%$ & $100 \%$ & $100 \%$ & $96.9 \%$ & $12.5 \%$ & $3.2 \%$ \\
\hline svitci & $90 \%$ & $76 \%$ & $87.8 \%$ & $79.7 \%$ & $83.4 \%$ & $14 \%$ & $82 \%$ \\
\hline otpadci & $79 \%$ & $75 \%$ & $87 \%$ & $89.3 \%$ & $82.6 \%$ & $14.3 \%$ & $45.7 \%$ \\
\hline ostaci & $57 \%$ & $66 \%$ & $58 \%$ & $58.9 \%$ & $60 \%$ & $9 \%$ & $59.4 \%$ \\
\hline žabovlatci & $66 \%$ & $64 \%$ & $67 \%$ & $58.9 \%$ & $64 \%$ & $8.1 \%$ & $58.3 \%$ \\
\hline privitci & $70 \%$ & $61 \%$ & $70 \%$ & $66.9 \%$ & $67 \%$ & $9 \%$ & $66.1 \%$ \\
\hline usadci & $97 \%$ & $99 \%$ & $98.3 \%$ & $100 \%$ & $98.6 \%$ & $1.3 \%$ & $82.3 \%$ \\
\hline nacrtci & $100 \%$ & $98 \%$ & $98.1 \%$ & $100 \%$ & $98.7 \%$ & $2 \%$ & $69.4 \%$ \\
\hline suci & $75 \%$ & $71 \%$ & $70 \%$ & $76.8 \%$ & $72 \%$ & $5 \%$ & $71.7 \%$ \\
\hline sveci (from svetac) & $79 \%$ & $78 \%$ & $74.5 \%$ & $76.8 \%$ & $77.1 \%$ & $4.5 \%$ & $76.2 \%$ \\
\hline svetci (from svetak) & $71 \%$ & $79.2 \%$ & $84.9 \%$ & $82.5 \%$ & $73.4 \%$ & $13.9 \%$ & $59.5 \%$ \\
\hline curetci & $89 \%$ & $88 \%$ & $85.9 \%$ & $93.7 \%$ & $89.1 \%$ & $7.8 \%$ & $78.9 \%$ \\
\hline strelica & $74 \%$ & $93 \%$ & $67.9 \%$ & $78.5 \%$ & $78.3 \%$ & $25.1 \%$ & $43.4 \%$ \\
\hline brežuljak & $100 \%$ & $88 \%^{18}$ & $94.2 \%$ & $93.3 \%$ & $95.8 \%$ & $6.7 \%$ & $12.7 \%$ \\
\hline brježić & $90 \%$ & $0 \%^{19}$ & $93.4 \%$ & $90.9 \%$ & $91.4 \%$ & $3.4 \%$ & $11.1 \%$ \\
\hline grešnik & $80 \%$ & $87.5 \%$ & $90.4 \%$ & $83.1 \%$ & $85.2 \%$ & $10.4 \%$ & $57.4 \%$ \\
\hline bezgrešnik & $77 \%$ & $79 \%$ & $86.5 \%$ & $86.2 \%$ & $82.2 \%$ & $9.5 \%$ & $56.3 \%$ \\
\hline sprječavati & $38 \%$ & $74 \%$ & $66.2 \%$ & $72.6 \%$ & $62.7 \%$ & $36 \%$ & $30.2 \%$ \\
\hline unapređivati & $35 \%$ & $66 \%$ & $52 \%$ & $47.2 \%$ & $50 \%$ & $31 \%$ & $15 \%$ \\
\hline unaprjeđivati & $65 \%$ & $33 \%$ & $48 \%$ & $52.8 \%$ & $49.7 \%$ & $32 \%$ & $24.2 \%$ \\
\hline nećemo & $97 \%$ & $85 \%$ & $87.4 \%$ & $90.8 \%$ & $90 \%$ & $12 \%$ & $84.1 \%$ \\
\hline pogreške & $93 \%$ & $97 \%$ & $89.6 \%$ & $88.5 \%$ & $92 \%$ & $8.5 \%$ & $84.7 \%$ \\
\hline $\begin{array}{c}\text { Johnnyjevim (opposed to } \\
\text { Johnnyevim) }\end{array}$ & $61 \%$ & $28 \%^{20}$ & $54 \%$ & $49 \%$ & $54.7 \%$ & $12 \%$ & $17.2 \%$ \\
\hline $\begin{array}{c}\text { Johnnyevim (opposed to } \\
\text { Johnnyjevim) }\end{array}$ & $39 \%$ & $72 \%^{21}$ & $46 \%$ & $51 \%$ & $45.3 \%$ & $12 \%$ & $14.6 \%$ \\
\hline $\begin{array}{c}\text { Johnnyjevim/Johnnyevim } \\
\text { (opposed to } \\
\text { Džonijevim/Đonijevim) }\end{array}$ & $68 \%$ & $51 \%^{22}$ & $61 \%$ & $92.7 \%$ & $73.9 \%$ & $31.7 \%$ & $31.8 \%$ \\
\hline zadacima & $65 \%$ & $52 \%$ & $58.8 \%$ & $69.8 \%$ & $61.4 \%$ & $17.9 \%$ & $60.6 \%$ \\
\hline
\end{tabular}

\subsection{Average}

The column average 2012 - 2015 shows the mean value of the four years monitored. From the 41 monitored examples it can be concluded that the average of one orthographic form in relation to the alternative one can be from $45.3 \%$ to $100 \%$ (the average is $79.1 \%$, which means that the two opposite forms out of the 41 examples occur in the relation $8: 2$ ). The value of around 50 percentage points of the examples zadaci, unaprjedivati and Johnnyjevim points to the fact that both orthographic forms are equally distributed (zadatci, unapredivati,

\footnotetext{
${ }^{18}$ Not taken into account in statistical calculation of the average, the deviation index and the relevance index. See section 4.6.

${ }^{19} \mathrm{Ibid}$.

${ }^{20}$ Ibid.

${ }^{21}$ Ibid.

${ }^{22}$ Ibid.
} 
Johnnyevim). The high value of almost 100 percent of forms crjepovi, iscjedci and petci means that alternative orthographic forms (crepovi, iscjeci and peci) are non-existent or statistically marginal. Table 4 shows the forms listed with regard to the average of their occurrence in the monitored four academic generations.

Table 4. Forms sorted in accordance with the average occurrence 2012 - 2015 (excerpt from table 3)

\begin{tabular}{|c|c|}
\hline Examples & $\begin{array}{c}\text { Average } \\
2012-2015\end{array}$ \\
\hline crjepovi & $100 \%$ \\
\hline iscjedci & $99.7 \%$ \\
\hline petci & $99.2 \%$ \\
\hline nacrtci & $98.7 \%$ \\
\hline usadci & $98.6 \%$ \\
\hline grjehovi & $96.9 \%$ \\
\hline patci & $96.8 \%$ \\
\hline brežuljak & $95.8 \%$ \\
\hline bitci & $94.5 \%$ \\
\hline nebitci & $93 \%$ \\
\hline napredci & $92.6 \%$ \\
\hline pogreške & $92 \%$ \\
\hline brježić & $91.4 \%$ \\
\hline nećemo & $90 \%$ \\
\hline curetci & $89.1 \%$ \\
\hline pripovijetci & $86.6 \%$ \\
\hline grešnik & $85.2 \%$ \\
\hline redci & $84.4 \%$ \\
\hline napitci & $83.4 \%$ \\
\hline svitci & $83.4 \%$ \\
\hline otpadci & $82.6 \%$ \\
\hline
\end{tabular}

\begin{tabular}{|c|c|}
\hline bezgrešnik & $82.2 \%$ \\
\hline brjegovi & $79.5 \%$ \\
\hline strelica & $78.3 \%$ \\
\hline sveci (from svetac) & $77.1 \%$ \\
\hline zagonetci & $75.5 \%$ \\
\hline $\begin{array}{r}\text { Johnnyjevim/Johnnyevim } \\
\text { (opposed to Džonijevim/Đonijevim) }\end{array}$ & $73.9 \%$ \\
\hline svetci (from svetak) & $73.4 \%$ \\
\hline suci & $72 \%$ \\
\hline preci & $71.1 \%$ \\
\hline privitci & $67 \%$ \\
\hline žabovlatci & $64 \%$ \\
\hline sprječavati & $62.7 \%$ \\
\hline zadacima & $61.4 \%$ \\
\hline ostaci & $60 \%$ \\
\hline podaci & $56.6 \%$ \\
\hline zadaci & $54.9 \%$ \\
\hline $\begin{array}{r}\text { Johnnyjevim } \\
\text { (opposed to Johnnyevim) } \\
\end{array}$ & $54.7 \%$ \\
\hline unapređivati & $50 \%$ \\
\hline unaprjeđivati & $49.7 \%$ \\
\hline $\begin{array}{r}\text { Johnnyevim } \\
\text { (opposed to Johnnyjevim) }\end{array}$ & $45.3 \%$ \\
\hline
\end{tabular}

\subsection{Deviation index}

The column Deviation index represents the difference between the highest and the lowest result in the four years observed. The reason for introducing this measurement is twofold: the first is to establish the credibility of writing - the spelling of a specific example is not expected to change substantially during one year. The second reason is to recognise changes in spelling. The deviation index average during all years for 526 students amounts to $11.05 \%$. The lower the value of the deviation index, the more uniform are the results in the four years observed. Thus, the form crjepovi with value 0 means that all four generations of students, as compared to the form crepovi, wrote in a completely uniform manner (in other words, no-one wrote crepovi). The value 100 would mean a total change of spelling. The deviation index shows that the declination of the name Johnny, as well as the jat reflection forms, str(j)elica, unapr(j)eđivati and spr(j)ečavati have high spelling deviations.

A great majority of questionnaire items show very small deviations per year: a quarter of the examples (11, i.e. $26.9 \%$ ) deviate in results by only $5 \%$, half of the questions $(24$, i.e. $58.5 \%)$ up to $10 \%$, five sixths $(34$, i.e. $82.9 \%)$ up to $15 \%$, and only each sixth example ( 7 questions or $17 \%$ ) have a more significant deviation during four years. ${ }^{23}$

This data lead to the conclusion that the surveyed students write in a relatively uniform manner.

\footnotetext{
${ }^{23}$ Due to a mistake which happened during the survey in academic year 2012/2013, as stated in the section ,Authenticity of survey and results”, the diminutive forms of "brijeg" and locative forms of "Johnny" are statistically not included into the calculation of the deviation index since it would be artificially increased. The average was calculated for the remaining three years.
} 
The deviations were, as expected, greater in examples with more than one orthographic form of the word requested (e.g. locative of Johnny, imperfective form of unaprijediti and spriječiti and diminutive of strijela). In case of binary forms, the students have shown an above average writing uniformity in the observed four-year period.

The deviation indices per group can be depicted as follows.

\section{The deviation index distribution}

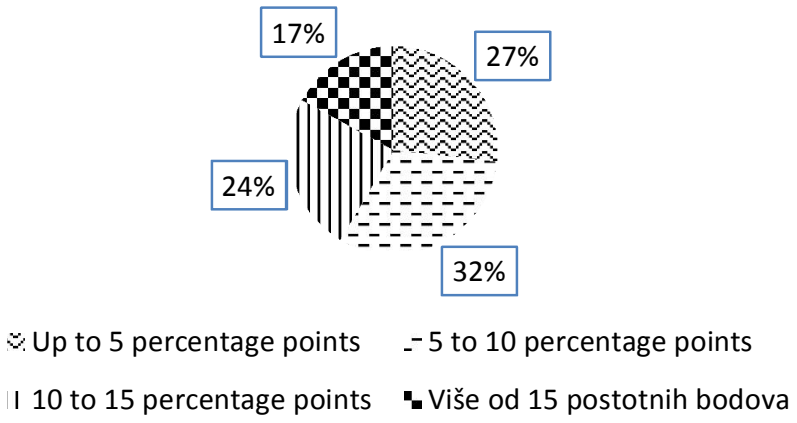

Picture 1. The deviation index distribution

\subsection{Relevance index}

The relevance index shows the average of the results of occurrence of the stated orthographic form not only in relation to its alternative orthographic form, but to all other forms which occurred in the questionnaire. It is provided in order to facilitate correct statistical interpretation of the questionnaire results since the information on average of the relation between the two forms is not sufficient without information on general acceptance. Thus, for instance, the information on the questionnaire results for the relation grehovi-grjehovi, in which as many as $97 \%$ would choose the latter form, can be contrasted with the information from the same survey that the dominant form grjehovi, as compared to all other orthographic forms which occurred, was chosen by only three of average 100 students. Similarly, the form crjepovi has a one-hundred-percent predominance in relation to crepovi, but its relevance is only $12.7 \%$. The form preferred by 83 out of 100 students is crijepovi, which is orthographically not standard at all (by all orthographic manuals). A high value of the relevance index is a strong indicator that a certain form is wide spread.

Table 5. Relevance index ranked from the highest to the lowest (excerpt from table 3)

\begin{tabular}{|c|c|}
\hline Examples & Relevance index \\
\hline petci & $90.3 \%$ \\
\hline bitci & $86.1 \%$ \\
\hline nebitci & $85.2 \%$ \\
\hline pogreške & $84.7 \%$ \\
\hline nećemo & $84.1 \%$ \\
\hline patci & $83.7 \%$ \\
\hline napitci & $82.4 \%$ \\
\hline usadci & $82.3 \%$ \\
\hline svitci & $82 \%$ \\
\hline curetci & $78.9 \%$ \\
\hline sveci (from svetac) & $76.2 \%$ \\
\hline iscjedci & $74 \%$ \\
\hline suci & $71.7 \%$ \\
\hline
\end{tabular}

\begin{tabular}{|r|l|}
\hline zagonetci & $70.8 \%$ \\
\hline nacrtci & $69.4 \%$ \\
\hline privitci & $66.1 \%$ \\
\hline zadacima & $60.6 \%$ \\
\hline svetci (from svetak) & $59.5 \%$ \\
\hline ostaci & $59.4 \%$ \\
\hline žabovlatci & $58.3 \%$ \\
\hline grešnik & $57.4 \%$ \\
\hline napredci & $56.3 \%$ \\
\hline bezgrešnik & $56.3 \%$ \\
\hline podaci & $54.5 \%$ \\
\hline zadaci & $54.2 \%$ \\
\hline preci & $53.1 \%$ \\
\hline redci & $50.8 \%$ \\
\hline
\end{tabular}




\begin{tabular}{|r|c|}
\hline otpadci & $45.7 \%$ \\
\hline strelica & $43.4 \%$ \\
\hline pripovijetci & $36.7 \%$ \\
\hline $\begin{array}{r}\text { Johnnyjevim/Johnnyevim } \\
\text { (opposed to Džonijevim/Đonijevim) }\end{array}$ & $31.8 \%$ \\
\hline sprječavati & $30.2 \%$ \\
\hline unaprjeđivati & $24.2 \%$ \\
\hline Johnnyjevim & $17.2 \%$ \\
\hline (opposed to Johnnyevim) & \\
\hline
\end{tabular}

\begin{tabular}{|r|c|}
\hline unapređivati & $15 \%$ \\
\hline $\begin{array}{r}\text { Johnnyevim } \\
\text { (opposed to Johnnyjevim) }\end{array}$ & $14.6 \%$ \\
\hline crjepovi & $12.7 \%$ \\
\hline brežuljak & $12.7 \%$ \\
\hline brježić & $11.1 \%$ \\
\hline brjegovi & $9.5 \%$ \\
\hline grjehovi & $3.2 \%$ \\
\hline
\end{tabular}

\subsection{Writing uniformity index}

The writing uniformity index resulted from the sum of the 2012 - 2015 average and the relevance index, and has the value of 132.7 as the mean of 41 examples in the four survey years.

A high value of the 2012 - 2015 average and of the relevance index provide a clear confirmation of a certain orthographic form. Their sum in the maximum value of $200 \%$ would represent the conclusion that all students prefer a certain spelling and that there is no other option in view of an alternative orthographic form. This sum value entitled writing uniformity index is presented in table 6 as final survey results. The term writing uniformity index seems representative since it provides for a vivid presentation of the survey results with regard to the criterion of result quality encompassing two levels of relative statistical ratios.

A high value of the 2012 - 2015 average, but with a low relevance index represents the already described situation in which students obviously prefer one form in relation to the alternative standard orthographic spelling, which however is not statistically relevant (example with grjehovi and crjepovi).

Table 6. Ranking of writing uniformity index as a sum of the 2012 - 2015 average and the relevance index

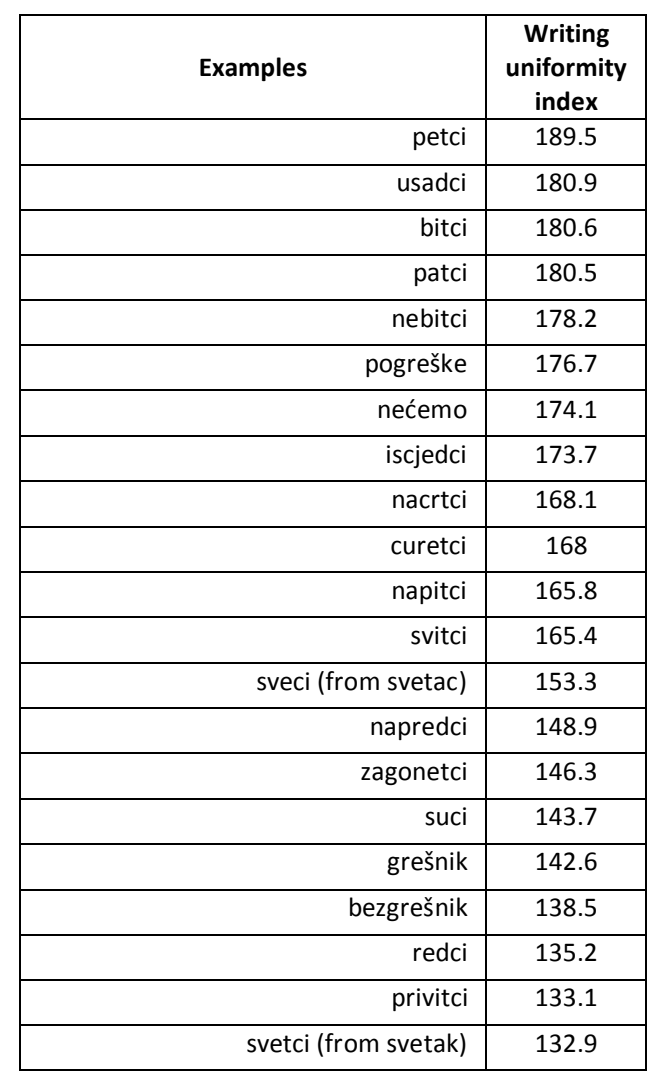

\begin{tabular}{|c|c|}
\hline otpadci & 128.3 \\
\hline preci & 124.2 \\
\hline pripovijetci & 123.3 \\
\hline žabovlatci & 122.3 \\
\hline zadacima & 122 \\
\hline strelica & 121.7 \\
\hline ostaci & 119.4 \\
\hline crjepovi & 112.7 \\
\hline podaci & 111.1 \\
\hline zadaci & 109.1 \\
\hline brežuljak & 108.5 \\
\hline $\begin{array}{r}\text { Johnnyjevim/Johnnyevim } \\
\text { (opposed to Džonijevim/Đonijevim) }\end{array}$ & 105.7 \\
\hline brježić & 102.5 \\
\hline grjehovi & 100.1 \\
\hline sprječavati & 92.9 \\
\hline brjegovi & 89 \\
\hline unaprjeđivati & 73.9 \\
\hline $\begin{array}{r}\text { Johnnyjevim } \\
\text { (opposed to Johnnyevim) }\end{array}$ & 71.9 \\
\hline unapređivati & 65 \\
\hline $\begin{array}{r}\text { Johnnyevim } \\
\text { (opposed to Johnnyjevim) }\end{array}$ & 59.9 \\
\hline
\end{tabular}




\subsection{Categorization of orthographic controversy}

Based on the writing uniformity index the categorisation of orthographic controversy was established.

An orthographically stable status would be if all students chose one orthographic form and only it. The group of forms which fall into this category is called orthographically uncontroversial category. It is a state characterised by orthographically relevant examples, which all speakers would write in the same way, except in case of typing errors. The least controversial example is the plural form petci of the noun petak with a value of 189.5 , and the most controversial is the locative form of the name Johnny with a value of 59.9.

On the other hand, orthographic controversy of a very low degree includes examples which have a writing uniformity index above 175 and is called $\mathbf{5}^{\text {th }}$ level category of orthographic controversy. It includes the examples petci (as compared to peci), usadci (as compared to usaci), bitci (as compared to bici), patci (as compared to paci), nebitci (as compared to nebici), pogreške (as compared to pogrješke).

Orthographic controversy of a low degree includes examples which have a writing uniformity index of 150 to 175 and is called $4^{\text {th }}$ level category of orthographic controversy. It includes the examples nećemo (as compared to ne ćemo), iscjedci (as compared to iscjeci), nacrtci (as compared to nacrci), curetci (as compared to cureci), napitci (as compared to napici), svitci (as compared to svici) and sveci (from svetac; as compared to svetak).

Orthographic controversy of a medium degree includes examples which have a writing uniformity index of 125 to 150 and is called $\mathbf{3}^{\text {rd }}$ level category of orthographic controversy. It includes the examples napredci (as compared to napreci), zagonetci (as compared to zagoneci), suci (as compared to sudci), grešnik (as compared to grješnik), bezgrešnik (as compared to bezgrješnik), redci (as compared to reci), privitci (as compared to privici), svetci (from svetak; as compared to svetac) and otpadci (as compared to otpaci).

Orthographic controversy of a high degree includes examples which have a writing uniformity index of 100 to 125 and is called $\mathbf{2}^{\text {nd }}$ level category of orthographic controversy. It includes the examples preci (as compared to predci), pripovijetci (as compared to pripovijeci and pripovijetki), žabovlatci (as compared to žabovlaci and žabovlatki), zadacima (as compared to zadatcima), strelica (as compared to strjelica), ostaci (as compared to ostatci), crjepovi (as compared to crepovi), podaci (as compared to podatci), zadaci (as compared to zadatci), brežuljak (as compared to brježuljak), the originally spelled locative of the name Johnny (as compared to the phonetically adapted), brježić (as compared to brežić) and grjehovi (as compared to grehovi).

Orthographic controversy of a very high degree includes examples which have a writing uniformity index lower than 100 and is called $\mathbf{1}^{\text {st }}$ level category of orthographic controversy. It includes the examples sprječavati (as compared to sprečavati), brjegovi (as compared to brjegovi), unaprjeđivati (as compared to unapređivati), Johnnyjevim (as compared to Johnnyevim), unapređivati (as compared to unaprjeđivati) and Johnnyevim (as compared to Johnnyjevim).

Judging by the above categorization of orthographic controversy and the mean of all survey examples observed (value of 132.7), it could be established that the total controversy of the students' orthographic writing with regard to the words observed was on the $3^{\text {rd }}$ level or "moderately controversial".

The ratio of the groups of 41 survey examples in accordance with the level of orthographic controversy for 526 students during four academic years can be shown as follows: 


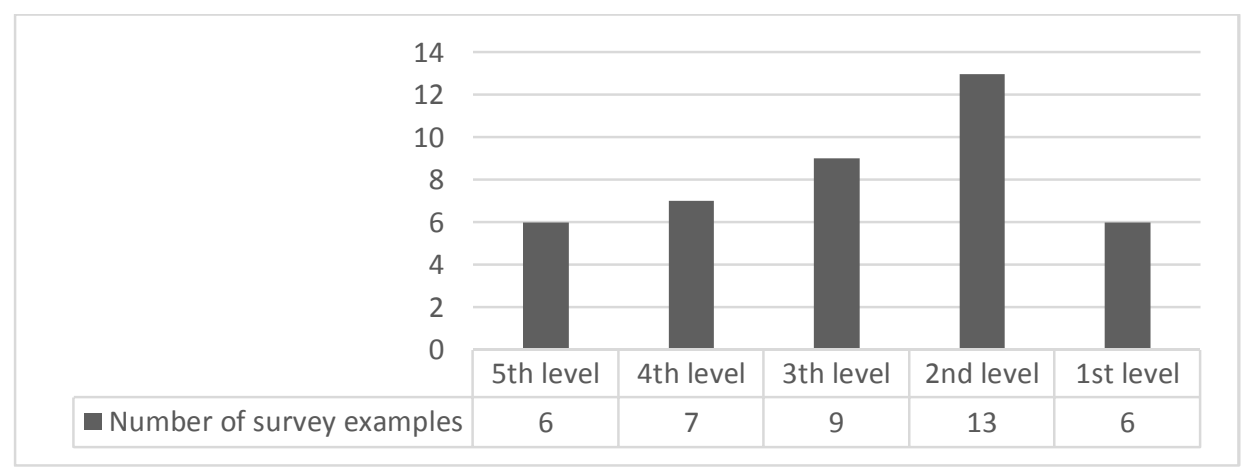

Picture 2. Survey examples and categorization of orthographic controversy

\subsection{Authenticity of survey and results}

In the entire research during four academic years only two pieces of survey data have not been included into calculation: data on locative of the name Johnny and data on the diminutive of the noun brijeg, both from academic year 2012/2013. During the survey an error occurred when several students said the solutions out loud, which lead to an artificially obtained result for these forms. Out of the wish for accuracy of survey methodology, the statistics of spelling of those two examples was left out in the calculation of the average, the deviation index and the relevance index.

\section{Conclusion}

The conclusions are divided into two groups: the ones related to survey results and the ones related to methodology and research.

With regard to survey results, the survey confirms that morphonological plural forms are significantly more often chosen with regard to phonological words ending in $-t a c,-t a k$, $-d a c$ and $-d a k$. This preference can be further analysed: the more analytical the approach to a word is (e.g. lexically or morphonologically less familiar word), the sooner will students choose the morphonologically derived word spelling. The more familiar the word is, the more students rely on its phonetic aspect and it is spelt following the phonological criterion.

Furthermore, it can be concluded that the writing of $j$ after the covered $r$ is relatively rarely represented, but students tend to avoid writing the ekavian form of $j a t$ and are thus even ready to make an orthographical mistake. Ekavian forms are present in Croatian dialect, but noteworthy in the Serbian standard language as well. Spelling of jat and of foreign names are places of greatest orthographic doubts. The least controversial are binary orthographic variations in which there is no possibility for alternative lexical and grammatical forms.

The compound spelling nećemo (as compared to non-compound spelling ne ćemo) is an orthographical issue of low controversy (belonging to the $4^{\text {th }}$ level of orthographic controversy).

We would also like to point out some statistical points of interest: the plural form of iscjedak was spelled in as many as 25 different forms. The students have written down 24 locative forms of the word Johnnyjevim, 33\% of which were written with a hyphen. A quarter of students chose the nonstandard plural of -dac as -tci (otpatci, retci). None of the 526 students wrote the standard form crepovi, while only one student wrote the standard forms iscjeci and grehovi. 
The thesis that the forms neću, zadaci and pogreška are considered "more neutral" because being used more often (e.g. Volanec 2015: 88) is a premise, which is only partially correct: this research shows that frequency does not have to mean orthographic neutrality. Following this logic it would be equally valid to say that the forms spriječavati, grijehovi, brijegovi, crijepovi, napitci and redci are more neutral because they occur more often with the participants of the survey as compared to the forms $g r(j)$ ehovi, br(j)egovi, $\operatorname{cr}(j)$ epovi, napici and reci. Until a corpus of standard written language is established for the needs of literacy monitoring, which would meet the criteria of representativeness, balance and dynamics, and until research is carried out including diverse groups of Croatian speakers (since orthography is not exercised only in journalism or in institutes of higher education), conclusions on stylistic neutrality based on frequency of some prototypical examples, as compared to the whole class, should be treated cautiously and one should abstain from scientific generalisation of this kind.

The thesis on the need of uniform spelling in schools is often brought forward by methodists since the youngest pupils have difficulties with accepting the spelling variants (Aladrović 2008, Reljac Fajs and Jerković 2013, Bežen 2005: 224). Students, as can be seen, cope very well with alternative writing of the svetci/sveci because they can differentiate the plural forms of svetak and svetac (77\% of them form sveci of the first word, and $79 \%$ svetci of the second word). ${ }^{24}$ In addition, words like petci and napitci are spelled using one pattern, while suci and podaci using another.

As to the results regarding methodology and research, it is considered that the questionnaire succeeded in monitoring the literacy level for a certain social group during a longer period, and the quantity of data collected meets the criterion of statistical relevance. The measurements and indices, such as the average and the deviation, relevance and writing uniformity indices, represent a good basis for further survey research in which final conclusions on the written language and orthographic literacy of young speakers of Croatian, after their twelveyear education in the Republic of Croatia, can be reached. A four-year survey continuity is not sufficient to be able to speak about monitoring orthographic habits or about orthographic diachronical course of standard writing, but such conclusions can certainly be made already after the first decade of conducting research.

Changes of orthographic rules, which have frequently happened in the recent period, represent an opportunity which should not be missed for accompanying sociolinguistic and language policy research on the relation of acquiring orthographic skills pursuant to the written standard. In regulated societies changes of spelling rules are no extraordinary events, but changes of orthographic paradigms are. In this perspective, monitoring the Croatian language context is especially rewarding.

Research will then be able to offer added value since we will be able to see the impact of the changed orthographic rules in schools and the level of acquiring orthographic habits in the monitored cases. The participating students were taught during their education in accordance to rules, which changed in 2013. It is due to this fact that we can test the hypothesis that a change of orthographic rules in the examples monitored does not have a substantial impact on the orthographic habits of students.

If the students of academic year 2011/2012 started primary school in 2000/2001, then the pupils who started first grade of primary school in the year when the orthographic manual of the IHJJ came into force (2013), will enrol

\footnotetext{
24 „Svetac“ (in Croatian a saint) and „Svetak“ (a religious holiday) have the same standard plural forms: „Sveci“ or ,"Svetci“.
} 
the Zagreb Polytechnic in 2024/2025, until when such research is planned. Comparison of orthographic habits will be conducted in four-year cycles. After this, the cycle from 2015/2016 to 2018/2019 and the cycle from 2019/2020 to 2022/2023 will follow. For each period, the writing uniformity index will be calculated facilitating the comparison of orthographic habits and spelling tendencies and testing of the established hypothesis. If the status of the recommended orthographic manual for Croatian does not change (IHJJ 2013) and if the prescribed rules do not change, the question arises what will happen with the students' spelling: will it keep the approximate value of the writing uniformity index of 132.7 or will it grow? Its decrease is considered to be least probable, and this scenario would surely open new and serious sociolinguistic questions on the Croatian orthographic standard and on the quality of native language education. On the level of orthographic planning, it will foster discussion on the introduction of a flexible standard, but also give rise to research on destandardisation factors in Croatian. If the value stays on the level calculated in years $2012-2015$, the hypothesis on orthographic habits as compared to the rules of orthographic manuals based on the cases monitored can be confirmed. An increase of the value will confirm the assumption that traditionally recommended forms become dominant with time, which would support the hypothesis on evolutionary orthographic literacy.

In addition to orthographic planning, the solutions are expected to provide a wider picture of the quality of literacy education in Croatia. Such research would be even more informative if the conclusions were compared with the research results of a (still non-existent) monitor corpus of Croatian for the purpose of research on the contemporary written language. Based on two opinions - one on the harmonisation of the explicit norm and usage standard as precondition for efficient learning of the standard language (Katičić 2004: 9), and the other that acceptance and codification of the usage standard creates a positive attitude in speakers toward the standard language (Bugarski 1986: 140), Volanec emphasised orthographic usage as the priority criterion for establishing a writing standard (2015: 87). However, we would like to stress that the usage criterion is only one of orthographologic (normative) criteria. Usage standard is not always the key criterion which normativists should hold on to when reaching orthographic decisions. For each orthographic issue a hierarchy of orthographologic principles should be established and based on the found examples and contexts two extremes should be balanced: the tendency for consistency and the tendency for compromising. A precondition of such steps in orthographic planning is research on orthographic writing and literacy.

\section{Bibliography}

Aladrović, K. (2008). Kompetencije učenika prvog razreda u poznavanju pravopisa na kraju školske godine.

Metodika: časopis za teoriju i praksu metodikâ u predškolskom odgoju, školskoj i visokoškolskoj izobrazbi.

2008:9(16), 39-52

Alerić, M., Gazdić-Alerić, T. (2009). Pozitivan stav prema hrvatskome standardnom jeziku kao uvjet njegova uspješnijega ovladavanja. Lahor : časopis za hrvatski kao materinski, drugi i strani jezik, 1(7), Zagreb: Hrvatsko filološko društvo, 5-23.

Aram, D., Korat, O. (eds.) (2010). Literacy Development and Enhancement across Orthographies and Cultures. Springer 
AS: Anić, V., Silić, J. (1986). Pravopisni priručnik hrvatskoga ili srpskoga jezika, Sveučilišna naklada Liber Školska knjiga, Zagreb ${ }^{1} 1986,{ }^{2} 1987,{ }^{3}$ 1990, Pravopis hrvatskoga jezika, Novi Liber - Školska knjiga: Zagreb ${ }^{4} 2001$.

Asmussen, J. (2006). Towards a methodology for corpus-based studies of linguistic change. Contrastive observations and their possible diachronic interpretations in the Korpus 2000 and Korpus 90 Corpora of Danish. In D. Archer, P. Rayson, A. Wilson (eds.), Corpus linguistics around the world, Amsterdam/New York: Brill

Bakota, L. (2011). Pravopisna norma u udžbenicima. Jezik 58(4). Zagreb: Hrvatsko filološko društvo, 135-149

Barbaroša-Šikić, M., Češi, M. (2010). Praćenje, vrednovanje i ocjenjivanje pisanih radova učenika. In M. Češi (ed.), Hrvatski jezik u kontekstu suvremenog obrazovanja. Zagreb: Naklada Slap

Bašić, N. (2014). Jezični identiteti nesrpskih naroda u velikosrpskom programu državnoga sjedinjenja. Hrvatska revija 3. Zagreb: Matica hrvatska, 28-37

Bežen, A. (2005). Problem različitosti i standarda u početnom pisanju. Metodika: časopis za teoriju i praksu metodikâ u predškolskom odgoju, školskoj i visokoškolskoj izobrazbi. 2005:6(2), 210-227

BFM: Babić, S., Finka, B., Moguš, M. (1994). Hrvatski pravopis, second ed., Zagreb. ${ }^{1} 1971$. (forbidden). Reprints: London 1972, 1984 and Zagreb: Školska knjiga 1990. Further editions Zagreb: Školska knjiga ${ }^{3} 1995,{ }^{4} 1996$, ${ }^{5} 2000,{ }^{6} 2002,{ }^{7} 2003,{ }^{8} 2004,{ }^{9} 2006$.

BHM: Babić, S., Ham, S., Moguš, M. (2005). Hrvatski školski pravopis, first ed. Zagreb: Školska knjiga ${ }^{2} 2008$, ${ }^{3} 2009,{ }^{4} 2012$.

BMM: Badurina, L., Marković, I. i Mićanović, K. (2007). Hrvatski pravopis, first ed. Zagreb: Matica hrvatska ${ }^{2} 2008$.

Bugarski, R. (1986). Jezik u društvu. Beograd: Prosveta

Coulmas, F., Guerini, F. (2012). Literacy and writing reform. In B. Spolsky (ed.) Cambridge Handbooks of Language Policy. Cambridge University Press, 437-460

Eaden, J., Mayberry, M. K., Mayberry, J. F. (1999). Questionnaires: the use and abuse of social survey methods in medical research. Postgraduate Medical Journal 75(885), 397-400

Grgić, A., Udier, S. (2012). Pravopisna kompetencija na razini B1 u hrvatskome kao inome jeziku. Lahor: časopis za hrvatski kao materinski, drugi i strani jezik, 2(14), Zagreb: Hrvatsko filološko društvo, 204-220.

Hudeček, L. (2010). Pregled suvremenih hrvatskih pravopisa (različita rješenja i terminološka neusklađenost). In M. Češi (ed.), Hrvatski jezik u kontekstu suvremenog obrazovanja. Zagreb: Naklada Slap. 42-55

IHJJ 2013: Jozić, Ž. (principal ed.) (2013). Hrvatski pravopis. Zagreb: Institut za hrvatski jezik i jezikoslovlje

Joshi, M. R., Aaron, P. G. (eds.) (2006). Handbook of orthography and literacy. Routledge

Katičić, R. (2004). Hrvatski jezični standard. Zagreb: Hrvatska akademija znanosti i umjetnosti 
Lydeard, S. (1991). The questionnaire as a research tool. Family Practice 8(1), 84-91

McEnery, T. (2003). Corpus Linguistics. In R. Mitkov (ed.), The Oxford Handbook of Computational Linguistics. Oxford University Press, 448-463

Páll, S. (2009). Beleške uz jedno davno zaboravljenu anketu (Srpski književni glasnik: Anketa o srpsko-hrvatskim odnosima). Riječ. Časopis za filologiju 15(2), Rijeka: Hrvatsko filološko društvo, 253-267

Patekar, J. (2016). Razlike u uporabi pravopisnih znakova u hrvatskome i engleskome jeziku. Rasprave: Časopis Instituta za hrvatski jezik i jezikoslovlje 42/I (2016.). Zagreb, 147-166

Peti-Stantić, A., Langston, K. (2013). Hrvatsko jezično pitanje danas. Identiteti i ideologije. Zagreb: srednja europa

Reljac Fajs, E., Jerković, T. (2014). Pravopis u razrednoj nastavi hrvatskoga jezika. Hrvatski: časopis za teoriju i praksu nastave hrvatskoga jezika, književnosti, govornoga i pismenoga izražavanja te medijske kulture 1(XII), 37-55

Sinclair, J. (1982). Reflections on computer corpora in English language research. In S. Johansson (ed.), Computer corpora in English language research 1-6. Bergen.

Sinclair, J. (1991). Corpus, Concordance, Collocation. Oxford University Press

Stone, D. H. (1993). Design a questionnaire. British Medical Journal, 307(6914), 1264-1266

Street, B. (2013). Literacy in Theory and Practice: Challenges and Debates Over 50 Years. Theory Into Practice $52,52-62$

Škarić, I. (2005). Ije je je. In J. Hekman (ed.) Jezik na križu. Križ na jeziku. Rasprava o pravopisnim pravilima. Zagreb: Matica hrvatska, 80-87

Tadijanović, D. 2005. Svi moji pravopisi. In J. Hekman (ed.) Jezik na križu. Križ na jeziku. Rasprava o pravopisnim pravilima. Zagreb: Matica hrvatska, 103-105

Templeton, S. \& Bear, D. R. (2013). Development of Orthographic Knowledge and the Foundations of Literacy. Routledge

Težak, S. (1996). Teorija i praksa nastave hrvatskoga jezika 1. Zagreb: Školska knjiga

Udier, S. L. (2016). Glotodidaktički pogled na hrvatski pravopis. In: Strani jezici 44(2016) vol 2. Zagreb: Filozofski fakultet Sveučilišta u Zagrebu, 110-128

Volanec, V. (2015). Sociolingvističko istraživanje hrvatskoga pravopisa: društveni stavovi o eksplicitnoj normi. Jezikoslovlje 16.1 (2015), 69-102

ZEROJ 2005: Zajednički europski referentni okvir za jezike: učenje, poučavanje, vrednovanje. Zagreb: Školska knjiga. 


\section{Appendix 1: Questionnaire}

\begin{tabular}{|l|l|}
\hline mn. od petak & \\
\hline mn. od patak & \\
\hline mn. od iscjedak & \\
\hline mn. od redak & \\
\hline mn. od bitak & \\
\hline mn. od nebitak & \\
\hline mn. od predak & \\
\hline mn. od napredak & \\
\hline mn. od napitak & \\
\hline D od pripovijetka & \\
\hline D od zagonetka & \\
\hline mn. od crijep & \\
\hline mn. od zadatak & \\
\hline mn. od podatak & \\
\hline mn. od brijeg & \\
\hline mn. od grijeh & \\
\hline mn. od svitak & \\
\hline mn. od otpadak & \\
\hline mn. od ostatak & \\
\hline D od žabovlatka & \\
\hline mn. od privitak & \\
\hline mn. od usadak & \\
\hline mn. od nacrtak & \\
\hline mn. od sudac & \\
\hline mn. od svetac & \\
\hline mn. od svetak & \\
\hline mn. od curetak & \\
\hline
\end{tabular}

Umanjenica od strijela:

Umanjenica od brijeg:

Ako je osoba koja radi radnik, kako se zove osoba koja griješi:

Ako je osoba bez sreće nesretnik, kako se zove osoba bez grijeha:

Ako se od svršenoga „doseliti“ tvori nesvršeni „doseljavati“, kako od svršenoga spriječiti glasi nesvršeni oblik:

Kako od svršenoga unaprijediti glasi nesvršeni oblik:

Diktatna rečenica:

[ nećemo/ne ćemo ispravljati pogreške/pogrješke u Johnnyjevim/Johnnyevim

zadatcima/zadacima] 